\title{
A Enfermagem no processo embrionário da Fisioterapia
}

\author{
Silvio Jorge Chaim Melhado*
}

Hoje a Fisioterapia é amplamente conhecida como um curso de nível superior, sendo seus graduados profissionais liberais e autônomos, porém nem sempre foi assim. Apesar de todo o contexto histórico da antiguidade apontar para práticas de tratamentos utilizando-se de meios físicos, como a água, o calor e a massagem, é na Inglaterra do séc. XIX, em plena revolução industrial, que observamos o processo embrionário desta profissão, antes mesmo das duas Grandes Guerras que impulsionaram a reabilitação [1].

Enfermeiras dos hospitais ingleses começaram a se utilizar da massoterapia no auxílio aos enfermos, porém, por diversas razóes a prática adotada por essas profissionais foi se tornando independente, pois caracterizava uma nova possibilidade de trabalho para as mulheres. Assim, surgiram escolas de treinamento para ensinar cientificamente a massagem e a eletricidade com finalidades terapêuticas. Com o tempo observou-se a necessidade da inclusão de exercícios no tratamento das pessoas com problemas físicos [1].

Em julho de 1894 foi fundada a Society of Trained Masseuses (Sociedade das Massagistas Treinadas) que era um departamento do Instituto de Parteiras e do Clube das Enfermeiras Diplomadas tendo como uma das principais fontes de informação científica a seção da Sociedade de Massagem do Nursing Notes, publicação específica da enfermagem. Até então havia rejeição à participação profissional masculina [2].
Nos Estados Unidos, nesta época, a reabilitação ficava a cargo de mulheres treinadas e que tinham a denominação de "ginastas médicas". Com o advento da Primeira Guerra Mundial houve um aumento na demanda por profissionais para reabilitar os soldados lesados ou incapacitados para o mais próximo da normalidade, optando-se por candidatas graduadas em escolas de educação física ou enfermagem; ou treinadas por um ortopedista. Alguns médicos chegaram a propor que a pessoa ideal para fazer a Fisioterapia deveria ser uma "enfermeira treinada", capaz de aplicar eficazmente uma prescrição médica. Tanto na Inglaterra como nos Estados Unidos os salários destas profissionais eram menores que aqueles pagos aos enfermeiros militares [1].

A partir das décadas de 20 e 30, nestes países, assim como na Alemanha, Austrália, Canadá, Suécia e outros, surgem escolas formadoras de profissionais reabilitadores que utilizam exercícios e meios físicos sob a designação de cinesioterapeutas ou Fisioterapeutas. Porém o maior impulso viria após a Segunda Guerra [1].

No Brasil as primeiras cidades a contarem com clínicas de Fisioterapia foram Rio e São Paulo onde em 1951 foi aberto o primeiro curso pela USP com duração de um ano em período integral para a formação de técnicos "fisioterapistas" [3]. Em 1963 a Fisioterapia se tornou curso superior, porém com sua atuação subordinada aos médicos. Somente em 1969, 
quando o presidente Costa e Silva sofre um AVC (hemiplegia com afasia) que, sensibilizados pelo bom atendimento dado pelos fisioterapeutas, a Junta Militar resolve regulamentar a criação da profissão em 13 de outubro de 1969 [4].

A retirada da condição de paramédicos ocorreu em 1984, quando o presidente Figueiredo recebeu atendimento para uma hérnia de disco e, finalmente, em 19/12/1994 a identidade profissional do Fisioterapeuta foi reconhecida no Serviço Público Federal [4], atribuindo-lhe o direito de avaliar, orientar, prescrever e coordenar a Fisioterapia na saúde pública em geral, facultando-lhe, assim como a Enfermagem, a condição de membro de uma equipe multidisciplinar.

\section{Referências}

1. Oliveira VRC. Reconstruindo a história da fisioterapia no mundo. Revista Estudos Vida e Saúde (São Paulo) 2005;4:509-34.

2. Barclay J. In good hands: the history of the Chartered Society of Physiotherapy 1894-1994. Oxford: Butterworth-Heinemann; 1994. p.16.

3. Departamento de Fisioterapia, Fonoaudiologia e Terapia Ocupacional da Faculdade de Medicina da USP. [citado 2013 Out 18]. Disponível em URL: http://www.fm.usp.br/fofito

4. Conselho Federal de Fisioterapia e Terapia Ocupacional - COFFITO. [citado 2013 Out 18]. Disponível em URL: http://www.coffito.org.br 